\title{
Keefektifan Model Pembelajaran STAD terhadap Hasil Belajar Matematika Materi Bangun Ruang
}

\author{
Fikri Nur Syamsu ${ }^{1 *}$, Intan Rahmawati², Suyitno ${ }^{3}$ \\ ${ }^{123}$ Jurusan Pendidikan Guru Sekolah Dasar, Fakultas Ilmu Pendidikan, Universitas PGRI Semarang, Indonesia
}

\author{
A R T I CLEINFO \\ Article history: \\ Received 18 May 2019 \\ Received in revised form \\ 30 June 2019 \\ Accepted 15 July 2019 \\ Available online 25 August \\ 2019 \\ Kata Kunci: \\ Bangun Ruang, Keefektifan, \\ Pembelajaran STAD \\ Keywords: \\ Build Space, Effectiveness, \\ STAD Learning
}

\begin{abstract}
A B S T R A K
Tujuan penelitian ini adalah untuk mengidentifikasi efektif atau tidaknya model pembelajaran STAD terhadap hasil belajar matematika materi bangun ruang siswa kelas $V$ SDN 01 Doplang. Jenis penelitian ini adalah penelitian kuantitatif dalam bentuk Pre Eksperimental Design dengan jenis One Grup Pretest-Posttest. Populasi penelitian ini adalah seluruh siswa SDN 01 Doplang 2018/2019. Sampel yang diambil adalah 30 siswa dengan teknik sampling jenuh. Berdasarkan hasil analisis uji normalitas dengan $L_{\text {tabel }}=1,701$ diperoleh normalitas akhir dengan $\mathrm{L}_{0}=0,0056$ Karena $\mathrm{Lo}<\mathrm{L}_{\text {tabel }}$ maka hasil $\mathrm{H}_{0}$ diterima dan data berasal dari distribusi normal. Selanjutnya perhitungan uji $t$ hasil belajar $t_{\text {hitung }}$ lebih besar dari $t_{\text {tabel }}(12,751>1,701)$ maka $\mathrm{H}_{0}$ ditolak. Artinya terdapat perbedaan nilai hasil belajar lebih baik antara sebelum (pretest) dan sesudah (post-test) yang menggunakan model STAD. Jadi model STAD efektif terhadap hasil belajar Matematika materi bangun ruang siswa kelas V SDN 01 Doplang. Berdasarkan hasil penelitian ini saran yang dapat disampaikan adalah Model pembelajaran STAD dapat meningkatkan hasil belajar siswa, oleh karena itu guru perlu menerapkan model pembelajarn STAD dengan baik agar siswa lebih semangat dan antusias dalam mengikuti proses kegiatan belajar mengajar.
\end{abstract}

The purpose of this study was to identify whether or not the STAD learning model was effective against the mathematics learning outcomes of the building material in the fifth grade students of SDN 01 Doplang. This type of research is quantitative research in the form of Pre Experimental Design with the type of One Pretest-Posttest Group. The population of this study were all students of SDN 01 Doplang 2018/2019. The samples taken were 30 students with saturated sampling techniques. Based on the results of the analysis of the normality test with Ltable $=1.701$ the final normality is obtained with $L O=0.0056$ Because Lo <Ltabel then the result of $\mathrm{HO}$ is accepted and the data comes from the normal distribution. Furthermore, the calculation of the test results of tcounting is greater than t table $(12.751>1.701)$ then $\mathrm{HO}$ is rejected. This means that there are differences in the value of better learning outcomes between before (pretest) and after (post-test) using the STAD model. So, the STAD model is effective on Mathematics learning outcomes, the material for building space in fifth grade students of SDN 01 Doplang. Based on the results of this study, suggestions that can be conveyed are the STAD learning model can improve student learning outcomes, therefore teachers need to apply the STAD learning model properly so that students are more enthusiastic and enthusiastic in participating in the process of teaching and learning activities.

\footnotetext{
${ }^{1}$ Corresponding author.

E-mail addresses: fikrinursyamsu@gmail.com (Fikri Nur Syamsu)
} 


\section{Pendahuluan}

Pendidikan merupakan prioritas yang paling utama dan penting dalam meningkatkan sumber daya manusia sebagaimana tercantum dalam pembukaan UUD 1945 tujuan pendidikan nasional adalah "mencerdaskan kehidupan bangsa". Untuk mencapai tujuan pendidikan memerlukan suatu strategi dengan mengembangkan ilmu pengetahuan dan teknologi untuk menciptakan mutu pendidikan yang berkualitas. Menurut Undang-undang Republik Indonesia Nomor 20 Tahun 2003 tentang Sistem Pendidikan Nasional, Pasal 1 Ayat 1 berbunyi "Pendidikan adalah usaha sadar dan terencana untuk mewujudkan suasana belajar dan proses pembelajaran agar siswa secara aktif mengembangkan potensi dirinya untuk memiliki kekuatan spiritual keagamaan, pengendalian diri, kepribadian, kecerdasan, akhlak mulia, serta keterampilan yang diperlukan dirinya, masyarakat.

Menurut Hastut (2017) Faktor yang paling menentukan keberhasilan pendidikan/pengajaran adalah guru, sehingga guru sangat dituntut kemampuannya untuk menyampaikan bahan pengajaran kepada siswa dengan baik, untuk itu guru perlu mendapatkan ilmu pengetahuan tentang metode dan media pengajaran yang dapat digunakan dalam proses belajar mengajar. Salah satu upaya yang dapat dilakukan untuk meningkatkan kualitas pendidikan Indonesia adalah dengan cara merubah paradigma pembelajaran, dari pembelajaran yang berpusat pada guru (teachercentered) ke arah pembelajaran yang berpusat pada siswa (studentcentered). Teacher centered adalah suatu metode pembelajaran di managuru yang lebih mendominasi kelas.

Slameto (2010:2) belajar adalah suatu proses usaha yang dilakukan seseorang untuk memperoleh suatu perubahan tingkah laku yang baru secara keseluruhan, sebagai hasil pengalamannya sendiri dalam interaksi dengan lingkungan. Secara psikologi, belajar merupakan suatu proses perubahan yaitu perubahan tingkah laku sebagai hasil interaksi dengan lingkungannya dalam memenuhi kebutuhan hidupnya. Gegne dalam Slameto (2010:13) belajar ialah suatu proses untuk memperoleh motivasi dalam pengetahuan, keterampilan, kebiasaan, dan tingkah laku; belajar adalah penguasaan pengetahuan atau keterampilan yang diperoleh dari instruksi. Belajar adalah suatu proses yang dilakukan individu untuk memperoleh suatu perubahan tingkah laku yang baru secara keseluruhan, sebagai hasil pengalaman individu itu sendiri di dalam interaksi dengan lingkungannya. (Aunurrahman,2012:35).

Berdasarkan pendapat para ahli, peneliti menyimpulkan pengertian belajar adalah suatu proses perubahan perilaku positif yang membawa perubahan kearah yang diperoleh dari pengalaman. Slameto (2010:3) ciri-ciri belajar dibedakan menjadi enam yaitu:

a. Perubahan terjadi secara tidak sadar

Ini berarti bahwa seseorang yang belajar akan menyadari terjadinya perubahan itu atau sekurangkurangnya ia merasakan telah terjadi adanya suatu perubahan dalam dirinya. Misalnya ia menyadari bahwa pengetahuan bertambah, kecakapan bertambah dan kebiasaan bertambah.

b. Perubahan dalam belajar bersifat kontinu dan fungsional.

Sebagai hasil belajar, perubahan yang terjadi dalam diri seseorang berlangsung secara kesinambungan, tidak statis. Satu perubahan yang terjadi akan menyebabkan perubahan berikutnya dan akan berguna bagi kehidupan ataupun proses belajar berikutnya. Missal jika seorang anak belajar menulis, maka ia akan mengalami perubahan dari tidak dapat menulis menjadi dapatmenulis.

c. Perubahan dalam belajar bersifat positif dan aktif

Dalam perubahan, perubahan-perubahan itu senantiasa bertambah dan tertuju untuk memperoleh suatu yang lebih baik dari sebelumnya. Dengan demikian makin banyak usaha belajar itu dilakukan, makin banyak dan makin baik perubahan yang diperoleh.

d. Perubahan dalam belajar bukan bersifat sementara

Perubahan yang bersifat sementara atau temporer terjadi hanya untuk beberapa saat saja, seperti berkeringat, keluar air mata, bersin, menangis, dan sebagainya, tidak digolongkan sebagai perubahan dalam pengertian belajar. Perubahan yang terjadi karena proses belajar bersifat menetap atau permanen. Ini berarti bahwa perubahan tingkah laku yang terjadi setelah belajar akan bersifat menetap. Misalnya, kecakapan seorang anak dalam memainkan piano setelah belajar, tidak akan menghilang, melainkan akan terus dimiliki dan bahkan makin terus dipergunakan atau dilatih.

e. Perubahan dalam belajar bertujuan atau terarah

Ini berarti bahwa perubahan tingkah laku itu terjadi karena ada tujuan yang dicapai. Perbuatan belajar terarah kepada perubahan tingkah laku yang bener-bener disadari. Misalnya seorang yang belajar mengetik, sebelumnya sudah menetapkan apa yang mungkin dapat dicapai dengan belajar mengetik, atau tingkat kecakapan mana yang akan dicapainya. 
f. Perubahan mencakup seluruh aspek tingkah laku

Perubahan yang diperoleh seseorang setelah melalui suatu proses belajar meliputi perubahan keseluruhan tingkah laku. Jika seseorang belajar sesuatu, sebagai hasilnya ia akan mengalami perubahan tingkah laku secara menyeluruh dalam sikap, keterampilan, pengetahuan dan sebagainya.

Kline (1972) mengatakan bahwa Matematika adalah pengetahuan yang tidak berdiri sendiri, tetapi dapat membantu manusia untuk memahami dan memecahkan permasalahan sosial, ekonomi dan alam. Sementara Beth \& Piaget (1956) mengatakan bahwa yang dimaksud dengan matematika adalah pengetahuan yang berkaitan dengan berbagai struktur abstrak dan hubungan antar-struktur tersebut sehingga terorganisasi dengan baik. Di pihak lain, Reys dkk.,(2002) mengatakan bahwa matematika adalah studi tentang pola dan hubungan, cara berfikir dengan strategi organisasi, analisis dan sintesis, seni, bahasa, dan alat untuk memecahkan masalah-masalah abstrak dan praktis.

Soekamto dalam Suprijono (2016:53) model pembelajaran adalah kerangka koneptual yang melukiskan prosedur sistematis mengorganisasikan pengalaman belajar untuk mencapai tujuan belajar tertentu dan berfungsi sebagai pedoman bagi para perancangan pembelajran dan para pengajar merencanakan aktivitas mengajar. Suprijono (2016:53) Model pembelajaran merupakan landasan praktik pembelajaran hasil penurunan teori psikologi pendidikan dan teori belajar yang dirancang berdasarkan analisis terhadap implementasi kurikulum dan implikasinya pada tingkat operasional dikelas.

Menurut Laa (2017) metode kooperatif merupakan metode pembelajaran yang dapat meningkatkan kinerja siswa dalam tugastugas akademik, dan membantu siswa dalam mencapai tujuan pembelajaran. Model STAD menekankan pada aktivitas dan interaksi antara siswa untuk saling membantu dalam menguasai materi pelajaran, guna mencapai tujuan yang diharapkan, siswa di tempatkan dalam tim belajar agar bekerja sama dalam kelompok untuk menyelesaikan tugas yang diberikan oleh guru. Student Teams Achievement Division (STAD) merupakan salah satu strategi pembelajaran kooperatif yang di dalamnya beberapa kelompok kecil siswa dengan level kemampuan akademik yang berbeda-beda saling bekerja sama untuk menyelesaikan tujuan pembelajaran. Tidak hanya secara akademik, siswa juga dikelompokkan secara beragam berdasarkan gender, ras, dan etnis (Rusman, 2012, hal. 201). Menurut Kadang (2017) STAD merupakan variasi pembelajaran kooperatif yang paling banyak diteliti, dan merupakan model yang paling baik untuk memacu siswa agar saling mendorong dan membantu satu sama lain untuk menguasai keterampilan yang diajarkan guru. Slavin (2005:143) STAD merupakan salah satu metode pembelajaran kooperatif yang paling sederhana, dan merupakan model yang paling baik untuk permulaan bagi para guru yang baru menggunakan pendekatan kooperatif. Metode yang dikembangkan oleh Slavin ini melibatkan "kompetisi" antar kelompok. Siswa dikelompokkan beragam berdasarkan kemampuan, gender, ras dan etnis (Huda, 2011:116). Wina dalam Sutinah dkk mengemukakan bahwa model pembelajaran kelompok adalah rangkaian kegiatan belajar yang dilakukan oleh siswa dalam kelompok-kelompok tertentu untuk mencapai tujuan yang telah dirumuskan. Guru menyajikan pelajaran, dan kemudian siswa bekerja dalam tim mereka memastikan bahwa seluruh anggota tim telah menguasai pelajaran tersebut. Kemudian, seluruh siswa diberikan tes tentang materi tersebut, pada saat tes ini mereka tidak diperbolehkan saling membantu. Menurut Nikmah (2016) STAD adalah salah satu dari tipe pembelajaran kooperatif yang menekankan adanya kerjasama siswa secara berkelompok dalam memecahkan suatu masalah untuk mencapai tujuan belajar. Pembelajaran dengan model STAD mampu menciptakan pembelajaran yang aktif, inovatif, kreatif, dan menyenangkan bagi siswa selama proses pembelajaran. Pembelajaran yang demikian akan mampu membangkitkan semangat bagi siswa untuk belajar sehingga akan berpengaruh terhadap pencapaian hasil belajar siswa yang optimal. Menurut Juraini (2016) Pembelajaran kooperatif tipe STAD ini merupakan salah satu tipe dari model pembelajaran kooperatif dengan menggunakan kelompokkelompok kecil dengan jumlah anggota tiap kelompok 4-5 orang siswa secara heterogen. Diawali dengan penyampaian tujuan pembelajaran, penyampaian materi, kegiatan kelompok, kuis, dan penghargaan kelompok. Menurut Wardana (2017) Model pembelajaran kooperatif tipe STAD menekankan pada kerja sama kelompok. Dengan dilakukan kerja kelompok diharapkan akan melatih siswa untuk mengungkapkan pendapat dan meningkatkan pemahaman konsep secara bersama, serta dengan terjalinnya kerja sama kelompok dengan baik maka siswa dapat lebih memahami konsep yang ada dengan bantuan temannya. Keunggulan pembelajaran koopertatif tipe STAD terletak pada langkah-langkah pembelajaran yang diterapkan. Penerapan model pembelajaran kooperatif tipe STAD diharapkan mampu meningkatkan hasil belajar siswa. Keunggulan pembelajaran kooperatif tipe STAD yaitu siswa bekerja dalam kelompok sehingga siswa dapat memahami konsep materi yang ada dengan bantuan teman kelompok mereka. Menurut Widyastuti (2012) Keunggulan dari metode pembelajaran kooperatif tipe STAD adalah adanya kerja sama dalam kelompok dan dalam menentukan keberhasilan kelompok tergantung keberhasilan individu, sehingga setiap anggota kelompok tidak bisa menggantungkan pada anggota yang lain dengan menggunakan kuis-kuis individual pada tiap akhir pelajaran. Pembelajaran kooperatif tipe STAD menekankan pada aktivitas dan 
interaksi diantara siswa untuk saling memotivasi saling membantu dalam menguasai materi pelajaran guna mencapai prestasi yang maksimal. Menurut Muslimin dkk dalam Sutinah dkk pembelajaran kooperatif adalah pembelajaran yang mengutamakan pada interaksi dan kerjasama antar siswa didalam kelompok untuk mencapai tujuan belajar secara bersama-sama.

Menurut Slavin (2005:143) STAD terdiri atas lima langkah antara lain:

a. Presentasi kelas

Materi dalam STAD pertama-tama diperkenalkan dalam presentasi di dalam. Bedanya presentasi kelas dengan pengajaran biasa hanyalah bahwa presentasi tersebut haruslah benar-benar berfokus pada unit STAD. Dengan cara ini, para siswa akan menyadari bahwa mereka harus benar-benar memberi perhatian penuh selama presentasi kelas, karena dengan demikian akan membantu mereka mengerjakan kuis-kuis, dan skor kuis mereka menentukan skor tim mereka.

b. Team

Team terdiri dari empat atau lima siswa yang mewakili seluruh bagian dari kelas dalam hal kinerja akademik, jenis kelamin, ras dan etnis. Fungsi utama dari tim ini adalah memastikan bahwa semua anggota team benar-benar siap belajar, dan lebih khususnya lagi adalah untuk mempersiapkan anggotanya untuk bisa mengerjakan kuis dengan baik. Setelah guru menyampaikan materinya, tim berkumpul untuk mempelajari lembar kegiatan atau materi lainnya. Yang paling sering terjadi pembelajaran itu melibatkan pembahasan permasalahan bersama, membandingkan jawaban, dan mengkoreksi tiap kesalahan pemahaman apabila anggota tim ada yang membuat kesalahan.

c. Kuis

Setelah sekitar satu atau dua periode setelah guru memberikan presentasi dan sekitar satu atau dua periode praktik tim, para siswa akan mengerjakan kuis indvidual. Para siswa tidak diperbolehkan saling membantu dalam mengerjakan kuis. Sehingga tiap siswa bertanggung jawab secara individual untuk memahami materinya.

d. Skor kemajuan individual

Gagasan dibalik skor kemajuan individual adalah untuk memberikan kepada tiap siswa tujuan kinerja yang akan dapat dicapai apabila mereka bekerja lebih giat dan memberikan kinerja yang lebih baik dari pada sebelumnya.

e. Team Recognize

Team akan mendapatkan sertifikat atau bentuk penghargaan yang lain apabila skor rata-rata mereka mencapai kriteria tertentu. Skor tim siswa dapat juga digunakan untuk menentukan dua puluh persen dari peringkat mereka.

Menurut Hamdayama (2014:118), pembelajaran STAD memiliki kelebihan dan kekurangan sebagai berikut :

a. Kelebihan model pembelajaran STAD antara lain :

1) Siswa bekerjasama dalam mencapai tujuan dengan menjunjung tinggi norma-norma kelompok.

2) Siswa aktif membantu dan memotivasi semangat untuk berhasil bersama

3) Aktif berperan sebagai tutor sebaya untuk lebih meningkatkan keberhasilan kelompok.

4) Interaksi antar siswa seiring dengan peningkatan kemampuan mereka berpendapat.

5) Meningkatkan kecakapan individu

6) Meningkatkan kecakapan kelompok

7) Tidak memiliki rasa dendam

b. Kekurangan model pembelajaran STAD antara lain :

1) Kontribusi dari siswa berprestasi rendah menjadi kurang

2) Siswa berprestasi tinggi akan mengarah pada kekecewaan karena peran anggota yang pandai lebih dominan

3) Membutuhkan waktu yang lebih lama untuk siswa sehingga sulit mencapai target kurikulum.

Salah satu upaya yang dapat dilakukan untuk meningkatkan kualitas pendidikan Indonesia adalah dengan cara merubah paradigma pembelajaran, dari pembelajaran yang berpusat pada guru (teacher centered) ke arah pembelajaran yang berpusat pada siswa (studentcentered). Teacher centered adalah suatu metode pembelajaran di mana guru yang lebih mendominasi kelas.

Proses pembelajaran yang diberikan oleh pendidik harus dapat memberikan peluang bagi siswanya untuk mengembangkan potensi yang dimiliki, sehingga membentuk siswa yang cerdas, kreatif dan mendukung kemajuan bangsa. Siswa dalam mengembangkan potensinya, harus mempelajari beberapa mata pelajaran yang ada di sekolah. Struktur kurikulum SD/MI memuat delapan mata pelajaran, muatan lokal, dan pengembangan diri (Permendiknas No 22 Tahun 2006). Salah satu mata pelajaran yang wajib dipelajari adalah Matematika. 
Matematika memiliki peranan penting dalam mencapai tujuan pembelajaran karena matematika merupakan mata pelajaran yang mengajarkan siswa untuk berpikir secara logis, sistematis, analisis, kreatif dan dapat bekerja sama. Pentingnya matematika bagi siswa tidak sejalan dengan keberhasilan matematika dalam pembelajarannya. Matematika dianggap sebagai momok yang menakutkan bagi sebagian siswa. Hal tersebut secara langsung maupun tidak langsung mematikan minat siswa terhadap mata pelajaran matematika itu sendiri.

Begitu pentingnya peranan matematika seperti yang diuraikan di atas, hendaknya matematika dapat dikuasai sedini mungkin oleh para siswa dan menjadikan matematika sebagai salah satu mata pelajaran yang digemari. Namun pada kenyataannya di lapangan, khususnya di SD Negeri 01 Doplang Blora mata pelajaran matematika dianggap sebagai mata pelajaran yang menakutkan karena tingkat kesulitannya. Pembelajaran yang selama ini diterapkan hanya sekedar ceramah dan latihan soal sehingga membuat suasana kelas menjadi monoton.

Berdasarkan hasil diskusi yang dilakukan pada tanggal 3 November 2018 dengan Purnomo Hadi, S,Pd.SD selaku guru/wali kelas V SD Negeri Doplang, kegiatan pembelajaran di SD Negeri 01 Doplang Blora diwarnai oleh pendekatan yang menekankan pada; (1) Model belajar seperti pada umumnya yang hanya ceramah tanpa menggunakan model pembelajaran tertentu, sehingga kurang mampu merangsang siswa untuk terlibat aktif dalam proses pembelajaran; (2) Tidak ada media pembelajaran dengan inovasi baru sehingga siswa merasa sudah tidak tertarik lagi; (3) Guru kurang inovatif dalam menyusun dan melaksanakanproses pembelajaran yang menimbulkan anak kurang fokus karena kegiatan pembelajaran yang monoton; (4) Guru bertindak sebagai satu-satunya sumber belajar, kurangnya interaksi timbal balik antara guru dan siswa, dan hanya menggunakan buku paket sebagai acuan.

Dari uraian diatas, penulis memberi solusi dengan menerapkan model pembelajaran kooperatif tipe STAD untuk mengatasi masalah tersebut. Alasan peneliti menggunakan model pembelajaran kooperatif tipe $S T A D$ karena tipe ini belum pernah diterapkan oleh guru dalam proses pembelajaran matematika di kelas V SD Negeri Doplang Blora. Dengan penerapan model kooperatif tipeSTAD pada mata pelajaran matematika di kelas $\mathrm{V}$ akanmenambah variasi model pembelajaran yang menarik, menyenangkan, dan dapat melibatkan semua siswa dalam kelas untuk berpartisipasi secara aktif, dan serta dapat meningkatkan aktifitas dan kerjasama siswa dalam kelompok. Diharapkan melalui model pembelajaran kooperatif tipe $S T A D$ dapat membantu mempermudah siswa dalampemahaman konsep dan menyerap materi yang diajarkan sehingga dapat mempengaruhi hasil belajar siswa pada mata pelajaran matematika.

\section{Metode}

Berdasarkan masalah yang telah dikemukakan di atas, maka pendekatan penelitian yang akan digunakan dalam penelitian ini adalah kuantitatif. Menurut (Sugiyono, 2013:109) metode penelitian eksperimen adalah metode penelitian yang digunakan untuk mencari pengaruh perlakuan tertentu terhadap yang lain dalam kondisi yang terkendalikan. Metode penelitian ini menggunakan pre eksperimental design.

Teknik pengumpulan data merupakan langkah yang paling utama dalam penelitian, karena tujuan utama dari penelitian adalah mendapatkan data. Tanpa mengetahui teknik pengumpulan data maka peneliti tidak akan mendapatkan data yang memenuhi standar data yang ditetapkan (Sugiyono, 2015: 193). Teknik pengumpulan data yang digunakan dalam penelitian ini yaitu:

Dekomentasi pada penelitian ini digunakan untuk mengumpulkan data siswa sebagai pembuktian dan perbandingan perubahan siswa sebelum diberikan perlakuan dan sudah diberikan perlakuan dengan model pembelajarn STAD terhadap hasil belajar siswa kelas V SDN 01 Doplang. Dokumentasi yang diambil dalam penelitian ini adalah gambaran pada saat proses pembelajaran menggunakan model pembelajarn STAD. Dokumentasi yang akan digunakan dalam penelitian ini meliputi, daftar nama siswa kelas V SDN 01 Doplang, daftar hasil pretest dan posttest serta dokumentasi foto saat proses pembelajaran.

Peneliti melakukan wawancara secara langsung dengan guru kelas V SDN 01 Doplang yang bernama bapak Purnomo Hadi, S,Pd untuk mengetahui informasi yang berkaitan dengan penelitian. Hasil wawancara dijadikan acuan peneliti dalam pelaksanaan penelitian.

Tes dalam penelitian ini adalah seperangkat alat yang digunakan untuk mengukur pencapaian hasil belajar Matematika materi bangun datar kelas II SD N Ngesrep 01 Semarang. Tes yang akan digunakan dalam penelitian ini menggunakan tes tertulis berupa soal pilihan ganda. Tes akan dilakukan dua kali yaitu pemberian tes sebelum proses pembelajaran (Pretest) dan pemberian tes setelah proses pembelajaran (Posttest). 


\section{Hasil dan Pembahasan}

Berdasarkan pendapat para ahli, peneliti menyimpulkan pengertian belajar adalah suatu proses perubahan perilaku positif yang membawa perubahan kearah yang diperoleh dari pengalaman.

Berdasarkan penelitian yang sudah dilakukan SDN 01 Doplang khususnya kelas V. Penelitian ini bertujuan untuk mengetahui apakah model pembelajaran STAD efektif terhadap hasil belajar matematika materi bangun datar siswa kelas V SDN 01 Doplang. Dengan perbedaan hasil belajar kognitif ini antara siswa yang proses pembelajarannya tanpa menggunakan model pembelajaran STAD dengan siswa yang diberi treatment model pembelajaran STAD terjadi karena menggunakan perlakuan pembelajaran yang berbeda.

Pada tahap awal sebelum perlakuan dilakukan uji normalitas menggunakan uji Lilliefors terlebih dahulu pada nilai pretest Hal ini dilakukan untuk mengetahui apakah sampel tersebut berdistribusi normal atau tidak. Berdasarkan perhitungan yang dilakukan diperoleh bahwa nilai pretest berdistribusi normal.Hasil analisis data awal pretest dari uji normalitas diperoleh $L o=0,0069$ dan untuk Ltabel $=0,161$. Dari perhitungan tersebut maka dapat dikatakan bahwa nilai pretest berasal dari populasi berdistribusi normal karena L0 < Ltabel.

Dalam analisis data akhir digunakan data nilai posttest. Berdasarkan hasil analisis data akhir pada uji normalitas diperoleh $\mathrm{Lo}=0,0037$, untuk Ltabel $=0,161$. Kesimpulannya dari perhitungan tersebut maka dapat dikatakan bahwa sampel berasal dari populasi berdistribusi normal karena L0 < Ltabel.

Berdasarkan hasil analisis akhir yang telah dilakukan dengan uji normalitas menunjukkan bahwa kedua sampel berasal dari populasi yang berdistribusi normal, sehingga dilakukan uji one sample t-test. Dalam perhitungan uji t diperoleh harga thitung $=8,428$ dan ttabel $=2,045$. Karena ttabel $<$ thitung yaitu $8,428<2,045$ atau thitung $>$ ttabel $=8,428>2,045$ maka H0 ditolak dan Ha diterima atau dapat dikatakan bahwa rata-rata hasil belajar siswa dengan menggunakan model pembelajaran STAD nilai rata-rata nilai pretest 58,17 menjadi 81,33 pada post-test sehingga nampak selisih 23,16. Maka dapat disimpulkan bahwa model pembelajaran $S T A D$ dalam materi bangun ruang dapat meningkatkan hasil belajar siswa kelas $\mathrm{V}$ SDN 01 Doplang.

\section{Simpulan dan Saran}

Berdasarkan hasil penelitian yang telah dilaksanakan dapat disimpulkan bahwa model pembelajaran STAD efektif terhadap hasil belajar matematika materi bangun datar siswa kelas V SDN 01 Doplang. Dibuktikan dengan menggunakan uji $t$ diperoleh hasil thitung sebesar 8,428 dan koefisien tersebut signifikan pada taraf $5 \%$ dan $\mathrm{db}=29$ maka diperoleh ttabel sebesar $=2,045$ jadi nilai $\mathrm{t}$ hitung $>\mathrm{t}$ tabel. Dan meningkatnya jumlah siswa tuntas adalah 25, dari 30 siswa yang mengikuti tes dengan nilai rata-rata 81,33 . Melalui presentase jumlah siswa yang tuntas adalah $83,33 \%$ menunjukkan bahwa pembelajaran dengan menggunakan model pembelajaran STAD lebih efektif dari pada pembelajaran yang tidak menggunakan model pembelajaran STAD pada materi bangun datar kelas V SDN 01 Doplang. Berdasarkan hasil penelitian yang telah dilaksanakan dapat disimpulkan bahwa model pembelajaran STAD efektif terhadap hasil belajar matematika materi bangun datar siswa kelas V SDN 01 Doplang.

Berdasarkan kesimpulan di atas, maka ada saran yang ingin dipaparkan dari penelitian ini: 1) Diharapkan guru dapat mencoba menggunakan model pembelajaran STAD sebagai bentuk inovasi pembelajaran dan alternatif dalam pembelajaran matematika karena lebih banyak mengaktifkan siswa dalam proses belajar, meningkatlan kerjasama, dan interaksi sosial. 2) Bagi siswa, dengan pembelajaran menggunakan model pembelajaran STAD dapat membantu siswa meningkatkan hasil belajarnya, untuk itu diharapkan siswa mampu mengikuti pembelajaran dengan sebaik-baiknya agar hasilnya lebih maksimal. 3) Bagi peneliti, dengan diadakan penelitian ini dan hasilnya baik, maka dapat dijadikan salah satu referensi yang nantinya dapat diterapkan di sekolah tempat mengajar. 4) Bagi pembaca, penelitian ini dapat dijadikan salah satu referensi jika nantinya ingin menggunakan model pembelajaran STAD

\section{Daftar Rujukan}

Arikunto, Suharsimi. 2016. Dasar-Dasar Evaluasi Pendidikan. Jakarta: PT Bumi Aksara.

Bhoke, Wilibaldus. 2016. Pengaruh Model Pembelajaran Kooperatif Tipe Student Teams Achievement Division (STAD) dan Motivasi Belajar terhadap Hasil Belajar Matematika Siswa Kelas V SD Gugus 2 Kecamatan Bajawa Kabupaten Ngada-Flores.http://ejournal.stkip.ac.id (di unduh 7 Maret 2019). 
Hastut, Eka Fitri. 2017. Penerapan Model Pembelajaran Kooperatif Tipe STAD untuk Meningkatkan Kemampuan Berpendapat. Jurnal Pesona Vol. 3. No. 2 Hal. 133-143. Tersedia Pada: https://doi.org/10.26638/jp.443.2080.

Juraini, Muhammad Taufik, I Wayan Gunada. 2016. Pengaruh Model Pembelajaran Kooperatif Tipe STAD (Student Team Achievement Division) dengan Metode Eksperimen terhadap Keterampilan Proses Sains dan Hasil Belajar Fisika pada Siswa SMA Negeri 1 Labuapi Tahun Pelajaran 2015/2016. Jurnal Pendidikan Fisika dan Teknologi Volume II No 2 Hal. 80-85. Tersedia Pada : http://jurnalfkip.unram.ac.id/index.php/JPFT/article/view/293/0.

Karso. 2012. Pendidikan Matematika 1. Jakarta: Universitas Terbuka.

Kadang, ST. Aminah, Jonner Nainggolan. 2017. Pengaruh Model Pembelajaran Kooperatif Tipe Student Teams Achievment Division (STAD) terhadap Keaktifan dan Hasil Belajar Fisika pada Materi Gelomang Siswa Kelas XII IPA SMA Negeri 2 Kabupaten Sorong. Jurnal Ilmu Pendidikan Indonesia $\begin{array}{llllll}\text { Vol. } & 5 & \text { No. } & 1 & \text { Hal. 43-54. Pada: }\end{array}$ https://ejournal.uncen.ac.id/index.php/JIPI/article/view/236/208.

Laa, Neli, Hendri Winata, Rini Intansari Meilani. 2017. Pengaruh Model Pembelajaran Kooperatif Tipe Student Teams Achievement Division terhadap Minat Belajar Siswa. Jurnal Pendidikan Manajemen Perkantoran Vol. 2 No. 2 Hal. 139-148. Tersedia Pada : http://ejournal.upi.edu/index.php/jpmanper/article/view/00000.

Marsih, Wahyudi, Warsiti. 2009. "Model Pembelajaran Kooperatif Tipe STAD Untuk Meningkatkan Hasil Belajar Matematika Tentang Soal Cerita Pecahan Pada Siswa Kelas V Sekolah Dasar". http://jurnal.fkip.uns.ac.id (di unduh 8 Maret 2019).

Mudjiono dan Dimyati. 2009. Belajar dan Pembelajaran. Jakarta: PT Rineka Cipta.

Nikmah, Erlita Hidaya, Achmad Fatchan, Yuswanti Ariani Wirahayu. 2016. Model Pembelajaran Student Teams Achievement Divisions (STAD), Keaktifan dan Hasil Belajar Siswa. Jurnal Pendidikan Geografi Vol. 3 No. 3 Hal. 1-17. Tersedia Pada : http://journal.um.ac.id/index.php/pendidikangeografi/index.

Robert. E Slavin. 2005. Cooperative Learning Teori, Riset dan Praktik. Bandung: Nusa Media.

Rusman. (2012). Model-model pembelajaran, mengembangkan profesionalitas guru. Jakarta: Rajawali Pers.

Slameto. 2010. Belajar dan Faktor-Faktor yang Mempengaruhinya. Jakarta:PT Rineka Cipta.

Sudjana, Nana. 2013. Penilaian Hasil Proses Belajar Mengajar. Bandung: PT Remaja Rosdakarya.

Sugiyono. 2016. Metode Penelitian Pendidikan (Pendekatan Kuantitatif, Kualitatif, dan R\&D). Bandung: Alfabeta.

Wardana, Ika, Tinggi Banggali, Halimah Husain. 2017. Penerapan Model Pembelajaran Kooperatif Tipe Student Team Achivement Division (STAD) untuk Meningkatkan Hasil Belajar Siswa Kelas XI IPA Avogadro SMA Negeri 2 Pangkajene (Studi pada Materi Asam Basa). Jurnal Chemica Vol. 18 No. 1 Hal. 76 - 84. Tersedia Pada: http://ojs.unm.ac.id/chemica/article/view/4678.

Widyastuti, Tri Indah. 2012. Penerapan Model Pembelajaran Kooperatif Tipe Stad Berbasis Contextual Teaching And Learning (CTL) dalam Rangka Meningkatkan Prestasi Siswa untuk Mata Pelajaran Ilmu Pengetahuan Sosial Ekonomi. Jurnal Pendidikan Inssan Mandiri Vol. 1 No. 1 Hal. 1-15. Tersedia Pada: https://jurnal.uns.ac.id/jpim/article/view/16294/13230. 